\title{
SELECTION FOR LENGTH OF LIFE IN THE HONEYBEE (APIS MELLIFERA)
}

\author{
Jovan M. KULINČEVIC and Walter C. ROTHENBUHLER \\ Department of Entomology \\ The Ohio State University \\ Columbus, Ohio 43210
}

\begin{abstract}
SUMMARY
Two-way selection in the honeybee for long and short length of life in laboratory cages was carried out. The basic population of $\mathbf{4 3}$ colonies was tested and three long-lived and three short-lived colonies were selected as progenitors of the two lines. Long- and short-lived lines diverged, but did not differ significantly in the first selected generation. In the second generation, the two lines differed statistically at the 0.007 level of probability. This experiment demonstrates that length of life can be changed by selection. Consequently, breeders can add length of life to other desirable characteristics to increase honey production.
\end{abstract}

\section{INTRODUCTION}

During the second half of this century selection for different characteristics in honeybees has attracted the interest of several investigators of this beneficial insect.

O. W. Park and others after him (see Rothenbuhler, 1958; Cale and ROTHENBUHLER, 1975) have successfully selected honeybees for resistance to American foulbrood. MACKENSEN and NYE (1966) developed lines of bees for high and low collection of alfalfa pollen. KULINČEvić and ROTHENBUHLER (1975) selected for resistance and susceptibility to hairless-black syndrome (chronic bee paralysis), a disease of adult honeybees. RothenbuHLER, et al. (1979) demonstrated that it is possible to select bees for sugar-syrup hoarding in laboratory cages. TUCKER (1980) produced bees tolerant to carbaryl insecticide.

EL-DEEB (1952) investigated the length of life of different races of bees (Italian, Caucasian and Carniolan). His conclusion was that the Italian workers are shorterlived due to their intense activity of brood rearing and honey storing. If bee breeders 
could increase longetivy of Italian bees, EL-DEEB felt that this race would be even better for honey production.

FREE and SPENCER-BOOTH (1959) reported marked variations in the length of life of worker honeybees of different colonies, both during summer and winter. RINDERER and Sylvester (1978) also found highly significant differences among a group of colonies for length of life in worker bees. They theorized that selection and improvement of length of life would be feasible. ROTHENBuHLER (unpublished), selecting for resistance and susceptibility to American foulbrood, noticed that after several generations of selection, the Brown-line worker bees lived markedly longer than the Van Scoy-line workers.

MaURizio $(1959,1961)$ pointed out that length of life in honeybees is regulated by nutrition and brood rearing activity. She distinguished short-lived "summer bees " and long-lived "winter bees". According to her view, other factors such as genetically determined length of life, physiological old age, and work performed outside the colony, have little influence on the length of life of worker honeybees.

VeSELY (1965), observing caged bees, showed that workers' length of life was predominately influenced by nutrition and environmental conditions. Furthermore, he stated that hereditary differences were most evident under optimum feeding conditions and when bees were raised in their own colony. According to KePENA (1979), the life span of worker bees in the laboratory became shorter as inbreeding increased. The negative influence of inbreeding diminished with outcrossing to another stock.

Our earlier observations (KuLINĆEvić and ROTHENBUHLER, unpublished data) confirmed the presence of significant variation in length of life in common stock of Italian bees. Newly emerged worker bees were tested in laboratory cages and the average length of life ranged from 30.5 to 45.5 days. Differences among the colonies were highly significant.

In view of these actual variations of the length of life in worker bees from different colonies, and on the assumption that longer-lived bees could contribute more to beekeeping practice, we have undertaken two-way selection for length of life.

\section{MATERIALS AND METHODS}

This selection process started with $\mathbf{4 3}$ colonies from four different stocks of Italian bees which were tested in laboratory cages for length of life. From each colony 3 replicates of 50 worker bees were tested. These worker bees emerged in an incubator at $35^{\circ} \mathrm{C}$ and $50 \% \mathrm{RH}$. When they were $0-24$ hours old, the bees were put into laboratory cages described by KuLINCEvić et al. (1973). The bees in cages were supplied with $20 \mathrm{ml}$ of water, $20 \mathrm{ml}$ of sugar syrup 1:1 by volume and $1.5 \mathrm{mg}$ of YEACO pollen substitute (RINDERER and ELLIOTI, 1977) and maintained in an incubator. Every day the cages were checked for dead bees and the number that died during the previous 24 hours was recorded. As soon as 
$50 \%$ of the bees in a cage died, the testing was terminated and the $50 \%$ mortality point was utilized as a measure of length of life.

After the testing of these 43 colonies of basic stock was finished, the three mated queens whose workers showed the highest length of life were chosen to initiate the long-lived line and the three with the lowest length of life to start the short-lived line. These six matings (queens and sperms in their spermathecas) constituted the parental stock and were used to initiate six sub-lines as described by KULINCEvić and RoTHENBUHLER (1975). Eight to ten queens were reared from each of the six sublines, introduced to nucleus colonies, and each queen was inseminated with semen from one drone of a different subline.

When the brood from this first generation of selection was about to begin emerging, brood combs were taken to the incubator where bees emerged and were tested for length of life as described before. The same procedure was employed for the second generation of selection, with the difference that there were two tests each composed of three replicates. The mean of the six reps was used as the length of life of each line in the second generation.

\section{RESULTS, ANALYSES AND CONCLUSIONS}

The results are given in Table 1 and Figure 1. Analysis of variance of the first selected generation revealed no significant difference between lines at the 0.1 level of probability. The second selected generation, however, showed a highly significant difference between lines $(P=0.007)$. So another phenotypic characteristic of the honeybee can be changed by selection. The realized heritability is $13.1 \%$.

TABL. 1. Mean days and S.E. to 50 percent mortality in each generation of each line.

\begin{tabular}{c|c|c|c}
\hline \hline & \multicolumn{3}{|c}{ Generation } \\
\cline { 2 - 4 } & Parental & First Selected & Second Selected \\
\hline Long & \multirow{2}{*}{$32.7 \pm 0.81$} & $36.8 \pm 0.87$ & $42.3 \pm 0.48$ \\
Short & & $33.7 \pm 0.86$ & $38.5 \pm 0.58$ \\
\hline \hline
\end{tabular}

It may be surprising to see that life span was increased in the line selected for shorter life. This increase, moreover, is significant at the 0.0001 level of probability (Regression Coefficient $=3.02$ ). To understand this development, one must keep in mind that the environment also affects length of life. For instance, nutrition in the larval stage may vary from month to month or from year to year and affect life span, as a result of quality and quantity of pollen available. The number of nurse bees relative to the amount of brood nursed affects length of life (Unpublished; EISCHEN, 1980). In this selection experiment, differences in length of life between generations reflect environmental as well as genetic effects; differences between long- and short-lived lines within generations reflect largely genetic effects. 
The most desirable length of life for a honey producing bee would depend upon time and length of the nectar flows.

Received for publication in January 1982.

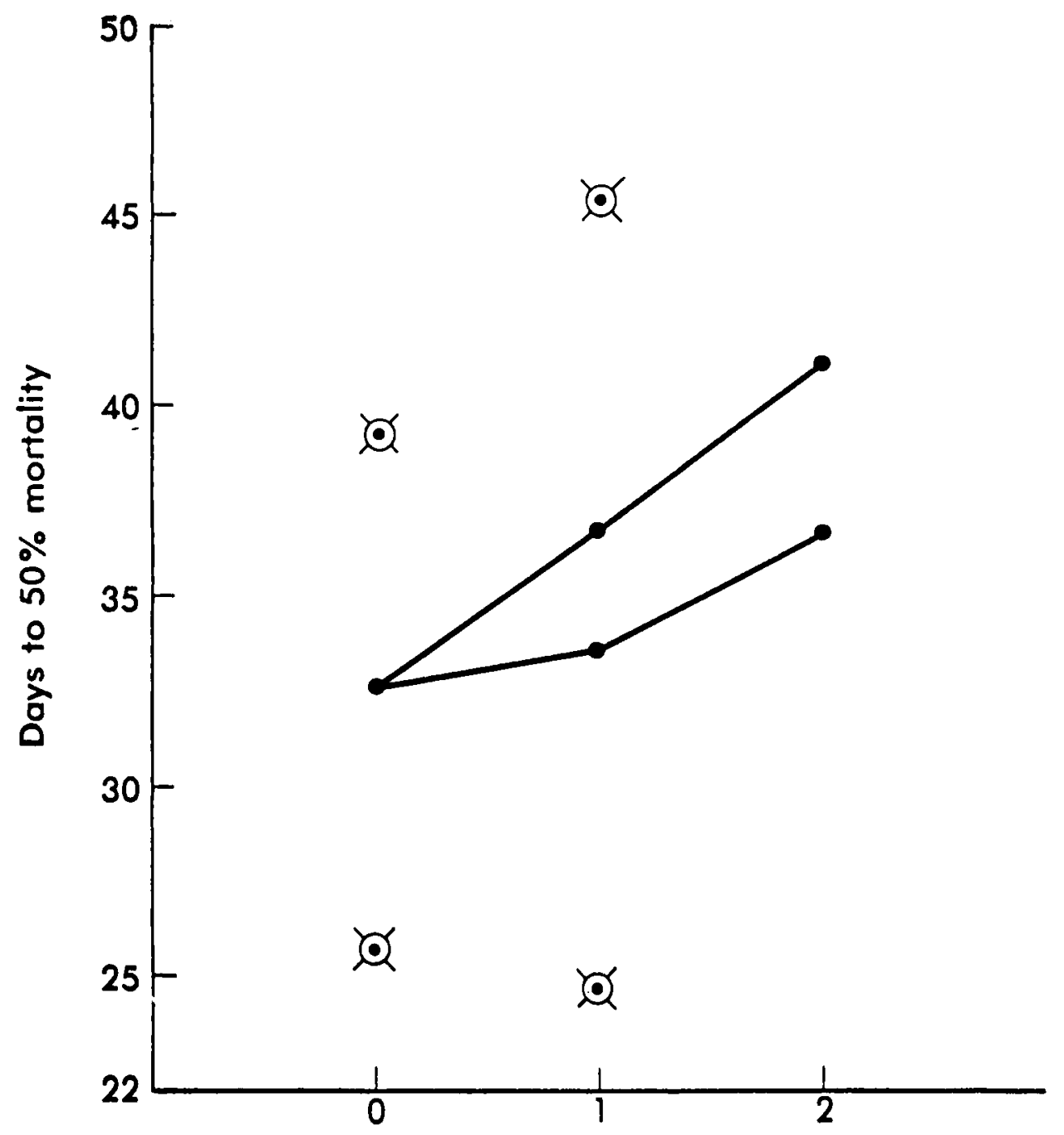

Generations of selection

FIG. 1. - Progress made in separating a long-lived and a short-lived line by two-way selection. Connected points are means from about 27 matings tested in each generation of each line. Points indicated by 0 are means of the 3 matings selected to produce the next generation. 


\section{RESUME}

SÉLECTION DE LA LONGÉVITÉ CHEZ L'ABEILLE (APIS MELLIFERA L.)

Des abeilles élevées en cagettes au laboratoire ont subi une sélection disruptive pour donner des lignées à vie courte et à vie longue. On a testé la population de départ, qui comportait 43 colonies, puis on a sélectionné 3 colonies à vie courte et 3 colonies à vie longue comme géniteur des 2 lignées. Il existait une différence entre la lignée à vie courte et celle à vie longue, mais elle n'était pas significative à la première génération sélectionnée. A la deuxième génération, les deux lignées différaient statistiquement au seuil de signification de 0,007 . Cette expérience prouve que la durée de vie peut être modifiée par la sélection. En conséquence les éleveurs peuvent ajouter la durée de vie à d'autres caractères souhaités pour accroître la production de miel.

\section{ZUSAMMENFASSUNG}

\section{SELEKTION AUF LEBENSDAUER BEI DER HONIGBIENE (APIS MELLIFERA)}

Eine Zwei-Wege Selektion auf Lang- und Kurzlebigkeit der Honigbiene wurde in Laborkäfigen durchgeführt. Die Basispopulation (bestehend aus 43 Kolonien) wurde zunächst getestet und dann drei langlebige und drei kurzlebige Kolonien als Parentalgenerationen der beiden Linien ausgewählt. Die langund kurzlebigen Linien divergierten, sie unterschieden sich aber in der ersten Generation nicht signifikant. In der 2. Generation differierten die beiden Linien jedoch statistisch auf dem Signifikanzniveau 0,007. Dieses Experiment zeigt, dass die Lebensdauer durch Selektion beeinflusst werden kann. Die Züchter können daher die Lebensdauer zusammen mit anderen erwünschten Merkmalen in der Selektion auf Steigerung der Honigproduktion einsetzen.

\section{LITERATURE CITED}

CAle G. H. Jr. and W. C. Rothenbuhler, 1975. - Genetics and breeding of the honey bee. In The Hive and the Honey Bee, pp. 157-184 (ed. by Dadant and Sons), Hamilton, 111.

EISCHEN Frank A., 1980. - The worker/larva ratio and its effect on the longevity of worker honey bees, Apis mellifera $L$. Ph. D. dissertation, The Ohio State University, Columbus, Ohio.

EL-DeEb A. L. A., 1952. - Longevity of some races of the honeybee (Apis mellifera). Ph. D. Thesis, University of Illinois, Urbana, 111.

FreE J.-B. and Y. SPENCER-BOOTH, 1959. - The longevity of worker honeybees. Proceedings Royal Entomological Society, London. A 34, 141-150.

KEPENA L., 1979. - Longevity in the laboratory of bees obtained by inbreeding and outbreeding. In : Genetics, Selection and Reproduction of the honey bee. Apimondia Publ., Bucharest, pp. 55-58.

Kulincevic J. M., W. C. RothenbuhleR and G. R. Stairs, 1973. - The effect of presence of a queen upon outbreak of a hairlessblack syndrome in the honey bee. J. Invertebr. Pathol, 21, 241-247.

Kulincevic J. M. and W. C. Rothenbuhler, 1975. - Selection for resistance and susceptibility to hairless-black syndrome in the honey bee. J. Invertebr. Pathol., 25, 289-295.

MACKenSEN O. and W. P. NYE, 1966. - Selecting and breeding honeybees for collecting alfalfa pollen. J. Apicultural Research, 5, 79-86.

Maurizio A., 1959. - Factors influencing the lifespan of bees. Pages 231-246 in Wolstenholme, G.E.W. and M. O'Connor. Ciba Foundation Colloquia on Aging, Volume 5: The Lifespan of Animals.

MaUrizio A., 1961. - Lebensdauer und Altern bei der Honigbiene (A. mellifera L.). Gerontologia, 5, 110 128.

RINDERER T. E., and K. D. ElLIOTT, 1977. - The effect of a comb on the longevity of caged adult honey bees. Annals of the Entomological Society of America, 70, 365-366. 
RINDERER T, E., and A. H. SYLVEsTER, 1978. - Variation in response to Nosema apis, longevity, and hoarding behavior in a free-mating population of the honey bee. Annals of the Entomological Society of A merlca, 71, 372-374.

ROTHENBUHLER W. C., J. M. KuLinĆEvić and V. C. THOMPSON, 1979. - Successful selection of honeybees for fast and slow hoarding of sugat syrup in the laboratory. J. Aplcultural Research, 18, 272-278.

RoTHENBUHLER W. C., 1958. - Genetics and breeding of the honeybee. Annual Review of Entomology, 3, 161-180.

TUCKER K. W., 1980. - Tolerance to carbaryl in honeybees increased by selection. American Bee Journal, $120: 36-37,39-41,46$.

VeSELY V., 1965. - Importance of hereditary longevity in honey bees. (Preliminary Report). Véd. Prace Vyskum. Ustav Včelar Č SAZV, 4 : 185-192. 